Рещикова Л.С.

Исследование признаков психологической безопасности образовательной среды школы и уровня школьной тревожности в рисунках детей младшего школьного возраста

Кафедра психологии развития и образования, Институт психологии, Российский государственный педагогический университет имени А.И. Гериена doi 10.18411/spc-12-01-2018-10

(Россия, Санкт-Петербург)

idsp 000001:spc-12-01-2018-10

Школа, как и другие образовательные организации, представляет собой социальный институт общества, обеспечивающий создание системы психологической безопасности. Однако школьная безопасность зачастую является мифической. Особую актуальность сегодня приобретает проблема защищенности от психологического насилия во взаимодействии участников образовательной среды школы. Это часто неучтенное, повседневное воздействие в большинстве случаев имеет серьезные последствия [2]. Психологическое благополучие школьника во многом определяется тем, насколько его учебная деятельность соответствует требованиям школы. Неблагополучие ребенка в школе проявляется, прежде всего, в высокой тревожности. Поэтому наряду с исследованием психологической безопасности часто измеряют уровень тревожности человека, способный также показать наличие внутреннего напряжения, а значит нарушения основной базовой потребности нашего организма в безопасности.

Дети раннего школьного возраста подвержены многим психологическим угрозам: ограничение самостоятельности, нарушение привычного ранее режима дня, игнорирование потребностей в сенсомоторной активности, игнорирование особенностей нервной системы и эмоциональных переживаний ребёнка [3].Появление в жизни ребенка новых субъектов - воспитателей и педагогов, неадекватный эмоциональный контакт с которыми будет также является своего рода угрозой его психологической безопасности [1]. Учащиеся начальной школы выступают специфической группой детей, психологическая безопасность которой обусловлена рядом особенных факторов внешней среды и внутренних состояний психики ребенка. Однако проблема психологической безопасности образовательной среды среди младших школьников остается мало изученной. В работе мы ставим цель исследовать этот вопрос с помощью формализованных методик и с помощью полученных данных предпринимаем попытку выделить показатели для измерения психологической безопасности младшего школьника на основе интерпретации его рисунка. Ведь именно детский рисунок вполне способен отразить самые тонкие аспекты миропонимания и переживания ребенка.

Проективные тесты, особенно рисуночные их варианты, легко выполняются детьми и позволяют провести диагностику в игровой форме, что крайне важно для младшего школьного возраста, поскольку дети данного возраста не обладают высокой степенью усидчивости и концентрации внимания. В силу своего возраста испытуемые не всегда могут четко сформулировать и понять смысл задаваемых тестовых вопросов. Именно поэтому дополнение используемых стандартизированных методик проективными методиками (с рисуночным, схематичным и другим стимульным содержанием) позволяет получить более достоверные и «читаемые» результаты. Однако в современной психодиагностике ощущается дефицит методик измерения психологической безопасности образовательной среды начальной школы.

Нами была выдвинута гипотеза, что оценка психологической безопасности образовательной среды ребенком связана с его уровнем тревожности и может быть выражена в рисунке. Было проведено исследование образовательной среды младшей 
школы, с целью измерения ее психологической безопасности, а также уровня тревожности обучающихся в ней детей. Для диагностики уровня тревожности младших школьников была использована методика Филлипса, направленная на изучение уровня школьной тревожности. Для измерения состояния психологической безопасности образовательной среды школы была применена методика «Психологическая безопасность образовательной среды» И.А. Баевой, специально адаптированная для категории младших школьников. Методика разделена на три части, фиксирующих показатели, по трем направлениям:

- отношение к образовательной среде школы (референтность образовательной среды);

- значимые характеристики образовательной среды школы и удовлетворенность ими;

- защищенность от различных форм психологического насилия во взаимодействии.

После заполнения указанных стандартизированных методик тем же испытуемым было предложено нарисовать на листе бумаги свою школу, друзей и учителя, а также подписать простым карандашом изображения.

Всего в исследовании приняли участие 379 детей из 16 школ Ленинградской области, 191 девочка и 188 мальчиков в возрасте 9-10 лет.

В результате полученных данных с использованием указанных методик были выделены 85рисунков испытуемых с повышенными высоким уровнем тревожности, 6 рисунков детей с низкой степенью удовлетворенности, а также 78рисунков ребят со средним и низким уровнем защиты от психологического насилия.

Выявлено, что из 70 младших школьников со средней степенью защиты от различных форм насилия во взаимодействии 29 являются тревожными. Из 8 ребят с низкой степенью защиты от различных форм насилия во взаимодействии 7 являются тревожными. Результат проведенного корреляционного анализа подтвердил существующую связь $(\mathrm{r}=-0,44)$ между показателями школьной тревожности и общим уровнем защиты от психологического насилия.

На втором этапе нашего исследования психологической безопасности образовательной среды школы проводилось тщательное изучение выделенных рисунков детей с школьной тревожностью, с низким уровнем защиты от психологического насилия, а также с низкой удовлетворенностью школьной средой, производился сравнительный анализ с рисунками испытуемых, не показавших какихлибо отклонений по стандартным методикам. По каждой из категорий были выделены признаки, указывающие на присутствие школьной тревожности, на низкую защиту от психологического насилия, а также на низкую удовлетворенностью школьной средой или же на отсутствие указанных отклонений. Проведена экспертная оценка выделенных признаков, с привлечением десяти специалистов.

Результатом проведенного согласования мнений экспертов стало выделение согласованных признаков по каждому из 4-х показателей (показано в \%). Так признаком школьной тревожности в рисунке младшего школьника будет являться:

- очень мелкое изображение фигур относительно листа и других предметов $(70 \%)$

- отсутствие опоры под ногами фигур на листе (70\%).

Признаком низкойзащиты от различных форм психологического насилия будет являться:

- общее впечатление негармоничного и тяжелого рисунка (90\%);

- слабое или наоборот очень сильное нажатие на карандаш (80\%);

- наличие неуверенных прерывистых линий (70\%).

Признаком низкой удовлетворенности школьной средой будет являться: 
- расположение фигур в нижней части листа (80\%);

- изображение себя снаружи школы (90\%);

- отсутствие изображения предметов окружения в рисунке (элементы декора, природы) (80\%).

Признаком низкого уровня школьной тревожности, высокого уровня защиты от различных форм насилия и уровня удовлетворенности школьной средой (то есть отсутствие отклонений) будет являться:

- изображение фигур с правильными пропорциями по отношению к листу и к другим объектам (70\%);

- рисунок занимает весь лист (70\%);

- изображенная школа имеет окна и двери (70\%).

На основе полученных данных нашей задачей на третьем этапе исследования будет анализ всех 379 рисунков с целью фиксации наличия или отсутствия согласованных признаков по выделенным 4-м показателям. Что позволит провести математический анализ полученных данных с результатами стандартных тестов и поможет определить возможность создания проективной методики адекватной возрастной категории младших школьников, которая смогла бы дополнить и подтвердить результаты стандартизированных тестов, а также сделать процесс выполнения задания интересным и увлекательным. Создание подобной методики поможет своевременно и оперативно исследовать состояние психологической безопасности образовательной среды в учебных заведениях, для создания комфортных условий обучения и взаимодействия всех участников образовательной среды, обеспечивая тем самым психическое здоровье и повышая школьную успеваемость.

$$
* * *
$$

1. Афонькина Ю.А. Психологическая безопасность ребёнка раннего возраста. Современные технологии. Программа адаптации. Диагностические методики. Игровой материал / Ю.А. Афонькина. - Волгоград: Учитель, 2013. - 105 с.

2. Баева И.А. Психологическая безопасность в образовании: монография. - СПб.: Союз, 2012. - 271 с.

3. Цапко, О.В. Психологическая безопасность образовательной среды в дошкольном образовательном учреждении // Наука 21 века: вопросы, гипотезы, ответы. - 2014. - №6. - С.106-108.

\section{Сахарова К.С. \\ Кросс-культурный аспект специфики страхов и тревожности детей из семей мигрантов}

ФГБОУ ВО «Пензенский государственный университет» (Россия, Пенза)

doi 10.18411/spc-12-01-2018-11

idsp 000001:spc-12-01-2018-11

Кросс-культурная специфика среды адаптации мигрантов $[2,3,4,8]$ не редко проявляется наличием факторов негативно влияющих на содержание процесса социально-психологической адаптации мигрантов к новым условиям жизнедеятельности. Дети из семей мигрантов испытав колоссальное эмоциональное потрясение, связанное с переездом в новое место жительства, сопряженное зачастую с травматическим опытом, оказываются в ситуации когда им приходится бороться с такими страхами, каких не испытывали их сверстники XX века. Изучением проявлений страхов у детей занимались

Н.Н. Авдеева, Ю.А. Кочетова, А.М. Прихожан, А. Токарев, А.С. Сержанова, А.К. Егенисова и др. Многочисленные эмпирические данные [1, 5, 6, 7] характеризуют негативную динамику, связанную с ростом количества детских страхов. Однако, работ 